\title{
A Severe Case of Cutaneous Myiasis in São Gonçalo, Brazil, and a Simple Technique to Extract New World Screw-Worm Cochliomyia hominivorax (Coquerel) (Diptera: Calliphoridae)
}

\author{
JA Batista-da-Silva ${ }^{1,2}$, GEM Borja ${ }^{1}$, MMC QueIroz $^{2}$ \\ ${ }^{1}$ Instituto de Biologia, Univ Federal Rural do Rio de Janeiro, Seropédica, RJ, Brasil \\ ${ }^{2}$ Lab de Transmissores de Leishmanioses (Setor de Entomologia Médica e Forense) do Instituto Oswaldo Cruz - IOC/FIOCRUZ, Rio de Janeiro, \\ RJ, Brasil
}

\section{Keywords}

Blowfly, public health, vaseline

\section{Correspondence}

José Antonio Batista-da-Silva, Programa de

Pós-Graduação em Biologia Animal

Universidade Federal Rural do Rio de

Janeiro, Rodovia BR-465, Km 7, 23890-000,

Seropédica (RJ), Rio de Janeiro, Brasil;

zeize@uol.com.br

Edited by Eunice Galati - FSP/USP

Received 18 October 2011 and accepted 17

April 2012

Published online 26 May 2012

(C) Sociedade Entomológica do Brasil 2012

Calliphoridae is one of the main muscoid families that are causal agents of myiasis to men and domestic animals in both rural and urban areas during their immature period (Zumpt 1965, Guimarães \& Papavero 1999). The infestation can be obligate or facultative according to the damage they cause. The obligate species parasitize living tissues and the facultative ones parasitize necrotic tissues (Zumpt 1965, Guimarães \& Papavero 1999). The species commonly involved in cases of obligate myiasis in Brazil is Cochliomyia hominivorax (Coquerel) (Guimarães \& Papavero 1999).

This paper is a case report of severe cutaneous myiasis recidivism and a description of a simple technique for the extraction of $C$. hominivorax larvae.

A 59-year-old man from an urban area of São Gonçalo, Rio de Janeiro, Brazil, had a recidivistic open wound on the right shoulder in January 2008 (summer) infested by fly larvae, which over a period of 7 days caused a skin lesion $12 \times 7 \mathrm{~cm}$.

In order to make the collection of larvae easier, the wound was washed with $500 \mathrm{~mL}$ of $0.9 \% \mathrm{NaCl}$ solution at room temperature to clean and remove any potential eggs of the fly. Solid vaseline was applied onto the wound and covered with a dressing (gauze and adhesive tape) to suffocate the larvae. After $90 \mathrm{~min}$, the larvae could be easily removed from the wound, demonstratin the technique could be used in substitution to the use of larvicides (ivermectin) or surgical extraction. The larvae that were not caught in the gauze were removed using sterile forceps and $0.9 \% \mathrm{NaCl}$ solution, leaving the wound completely clean (method modified from Batista-da-Silva et al 2009).

All larvae were collected at the São Gonçalo Alberto Torres State Hospital, which is the only one in the city with professionals trained to remove fly larvae and to identify and treat myiasis. All larvae were transferred to a container with $70 \%$ ethanol and sent to the "Laboratório de Vetores de Leishmaniose" ("Departamento de Entomologia Médica e Forense") at the "Instituto Oswaldo Cruz-IOC/FIOCRUZ", RJ, Brazil for identification. In the laboratory, the larvae were clarified with $10 \% \mathrm{KOH}$ for $24 \mathrm{~h}$, and then identified according to Guimarães and Papavero (1999).

A total of 287 first (79 larvae), second (141 larvae), and third instars (67 larvae) were identified as $C$. hominivorax, which featured several ovipositions by the females of this species. 
According to Robbins \& Khachemoune (2010), myiasis is the fourth most common parasitosis found in travelers. In South America, especially in Brazil, C. hominivorax is the most frequent species (Guimarães \& Papavero 1999, Batista-da-Silva et al 2011). Strategies to kill or remove fly larvae from human parasitized tissue include the application of ether, formaldehyde, Creolin, tobacco and sugar, but are not recommended (Batista-da-Silva et al 2011); other strategies include the use of ivermectin or surgical extraction.

According to Shinohara et al (2004), ivermectin is an antibiotic and its use was well documented for the control of fly larvae. Despite this effective control of parasites, ivermectin takes several hours to act, in which time irreversible muscle damage could occur to a patient (with a possible reduction of limb movements), especially if there are a large number of larvae. Surgical extraction, despite being highly efficient, has a high cost, and also requires the presence of a surgeon.

The occurrence of a parasitic disease where the individual has a large number of larvae in a single wound is rare and needs careful and fast extraction of the larvae, so the use of $\mathrm{NaCl}$ solution to wash the wound and remove the eggs, solid vaseline and dressing using gauze and adhesive tape to kill the larvae by suffocation is simple and can be applied by any health professional, reducing the time for extraction of the larvae and eliminating the costs of larvicides (ivermectin) or surgery.

Acknowledgments To the patient, for his participation in this study, by signing a term of accordance for the divulgation of data and so complying with the existing code of ethics and to David Graham Straker for the English revision.

\section{References}

Batista-da-Silva JA, Abádio HC, Queiroz MMC (2009) Human myiasis by Dermatobia hominis (Linnaeus Jr.) (Diptera, Cuterebridae) and Cochliomyia hominivorax (Cocquerel) (Diptera, Calliphoridae) in parasitic succession. EntomoBrasilis 2:61-63

Batista-da-Silva JA, Moya-Borja GE, Queiroz MMC (2011) Factors of susceptibility of human myiasis caused by the New World screw-worm, Cochliomyia hominivorax in São Gonçalo, Rio de Janeiro, Brazil. J Insect Sci 11:1-7

Guimarães JH, Papavero N (1999) Myiasis in man and animals in the Neotropical region. Bibliographic database. São Paulo, FAPESP/Editora Plêiade, p 308

Robbins K, Khachemoune A (2010) Cutaneous myiasis: a review of the common types of myiasis. Int J Dermatol 49:1092-1098

Shinohara EH, Martini MZ, Neto HGO, Takahashi A (2004) Oral myiasis treated with ivermectin: case report. Braz Dent J 15:79-81

Zumpt F (1965) Myiasis in man and animals in the Old World. Butterworth, London, p 267 